\title{
Fiscal Decentralization and Local Public Health Expenditure: Empirical Analysis Based on Different Caliber Indicators and Provincial Panel Data
}

\author{
Xiaohua Ning \\ Institute of Finance and Economics, Central University of Finance and Economics, Beijing, China
}

Email address:

ningxiaohua916@126.com

To cite this article:

Xiaohua Ning. Fiscal Decentralization and Local Public Health Expenditure: Empirical Analysis Based on Different Caliber Indicators and Provincial Panel Data. International Journal of Health Economics and Policy. Vol. 3, No. 3, 2018, pp. 32-39. doi: 10.11648/j.hep.20180303.12

Received: November 4, 2018; Accepted: November 19, 2018; Published: December 21, 2018

\begin{abstract}
Based on the construction of different caliber fiscal decentralization and local public health expenditure index, this paper makes an empirical analysis of the influencing factors of local public health expenditure in China by using the methods of FGLS and dynamic panel GMM. It is found that different fiscal decentralization indicators have different effects on public health expenditure, and local governments have a large right of financial autonomy to effectively increase public health expenditure, and the central government's transfer payment to local governments also has a significant positive effect on local public health expenditure. In addition, the difference in the level of local economic development will result in uneven local public health expenditure, manifested in the double imbalance between the expenditure structure and the provision of public health services. Therefore, China should continue to increase the central transfer payment, reasonably divide the central and local financial authority, establish a hard restraint mechanism of local public health expenditure, clarify the expenditure responsibility boundary between the central and local governments, and implement the measures of combining central supervision and control with local financial autonomy, in order to solve the problem of the double imbalance between regional and regional expenditure of local public health expenditure and ensure the effective supply of local public health products.
\end{abstract}

Keywords: Fiscal Decentralization, Public Health Expenditure, The Empirical Analysis, Different Caliber Indicators

\section{Introduction}

As a public product, the government has an unshirkable responsibility for its development. The government's fiscal expenditure and emphasis on public health determine the development speed and direction of public health, and affect the quality, accessibility and fairness of public health services [1]. Over the years, China is paying more and more attention to public health development and increasing fiscal investment, especially when the country's public health vulnerabilities exposed in the 2003 "SARS" events, the state has staged a series of legal policy to encourage the development of public health, such as "the state council on health reform and development of decision regulation" which was promulgated by the central committee of the CCP in 1997, it stipulated that the government's investment in health should increase year by year with the development of the economy, and the increase should not be lower than the growth of fiscal expenditure in that year. In 2009,
The executive meeting of the state council adopted the opinions of "the state council of the CPC central committee on deepening reform of the medical and health care system", which marked a new round of healthcare reform formally launched. It strengthened the government's responsibility in public health products, highlighted the government's leading role in providing and safeguarding public health, and called for the basic medical and health services for all as the fundamental starting point and goal, and the basic medical and health system as a public product to be provided to all. In the same year, the ministry of health, ministry of finance, the national population and family planning commission jointly issued the health care reform supporting documents of "recommendations for promoting progressive equalization of basic public health services", It called for governments at all levels to improve their input mechanism for public health and gradually increase public health input. By 2020, basic public health services will be gradually equalized, major diseases and major health risk factors will be effectively 
controlled, and the health level of urban and rural residents will be further improved. It can be said that since the reform and opening up, with the rapid economic development, China's public health input has been increasing continuously, especially after the tax distribution reform in 1994 (figure 1), China's medical and health service system has been increasingly sound.

However, compared with the rapid growth of GDP, the development of public health services in China lags behind, and many problems remain prominent: government health accounts for the proportion of the total health expenses is very low (figure 1), large medical expenses shall be borne by the society and individual, still in China's GDP has climbed the world's second today, the country's medical and health care spending as a share of GDP ranked 145th. Problems such as the shortage of total health resources, unreasonable structure, uneven distribution, relatively single supply subject, and weak service capacity at the grassroots level remain prominent. There is a clear gap between the basic medical and health services and the public's demand. "Expensive and difficult to get medical treatment" has become one of the most concerned social problems. It is difficult to achieve the equalization of public health services (figure 2), and the system to maintain and promote people's health needs to be constantly improved.

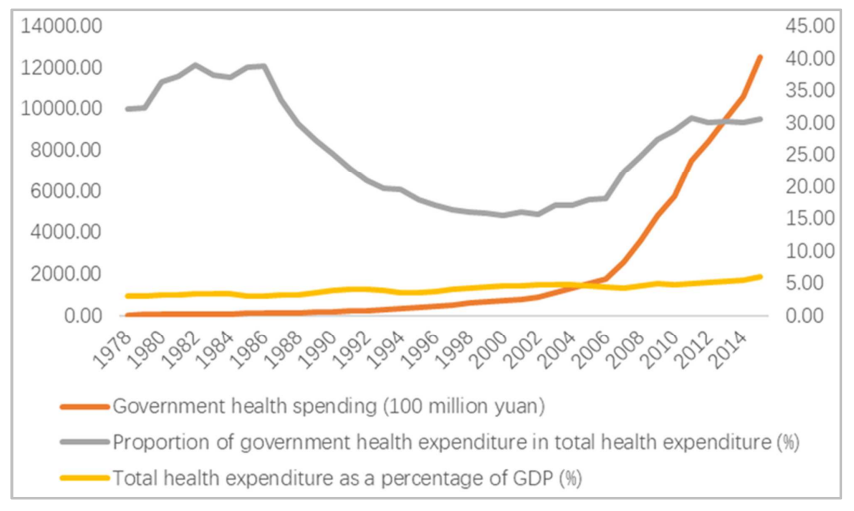

Figure 1. Government public health expenditure in China in recent years.

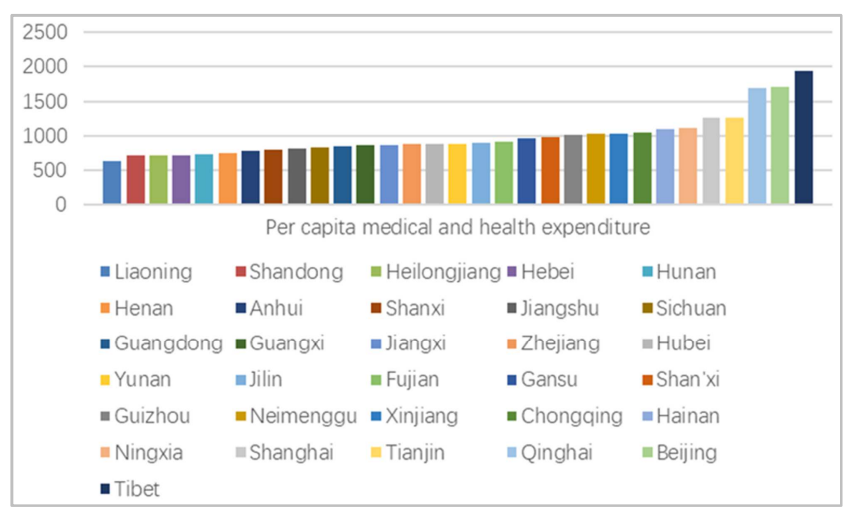

Figure 2. Public health expenditure per capita in China's provinces, municipalities and autonomous regions in 2015.

With the rapid development of China's economy and the continuous maturity of market-oriented reforms, why is there a shortage of public health investment? What factors affect the scale of government public health expenditures? According to economic theory, the sharing of fiscal expenditures between governments at all levels depends on the division of financial and power rights of governments at all levels, and the adoption of national laws stipulates the public affairs that governments at all levels should be responsible for. This provides a new perspective for the research in this study. How should we define the financial responsibility of governments at all levels in an effective public health supply mechanism? What is the impact of China's current fiscal decentralization system on government public health expenditure? How to deal with the relationship between the central and local governments, stimulate the enthusiasm of all levels of government to provide public health products, and achieve the goal of equalizing public health services? These are the concerns of this study.

From the perspective of fiscal decentralization, this study will empirically analyze the current situation of public health expenditures of local governments in China, and analyze the impact of fiscal decentralization and other relevant factors on public health expenditures of local government through panel data.

\section{Literature Review}

\subsection{Literature on the Influencing Factors of Public Health Expenditure}

As an important public product, public health service has been attached great importance to by the government and attracted many domestic and foreign scholars to study it from multiple perspectives. At present, there is no clear and unified definition of "public health" in China. Drawing on the research of Chen Gong and Wang Jun, public health refers to the public health goods (services) provided by public finance, including public health supervision, health education, dealing with unexpected public health events and infectious diseases. Correspondingly, public health expenditure refers to the sum of money provided by the government of a country (or region) to public health goods (services) through financial means within a certain period.

Scholars have given different answers to the research on the influencing factors of public health expenditure from different perspectives. Some scholars studied its impact on public health expenditure from the perspective of macroeconomic variables. Gerdtham and Johannesson found in their research that the increase of GDP in developing countries is conducive to increasing public health expenditure [2]. Newhouse also believes that there is a positive correlation between GDP and health expenditure [3]. Fatas and Rose found that the level of per capita national income, the proportion of dependent population and the degree of opening up of the economy positively affect the scale of fiscal expenditure [4]. Tanzi and Schuknecht found through research that urbanization is one of the important factors leading to the increase of public expenditure [5]. Saniay pointed out in his research that the overall level of public expenditure must be coordinated with the macroeconomic situation [6]. Grossman believes that 
improving education level can improve the efficiency of residents' health investment and thus reduce the demand for medical services [7].

Chinese scholar Chen Gong and Wang Jun believes that the current unreasonable structure and unfair distribution of public health expenditure in China are closely related to regional economic development level, regional financial resources, financial system, transfer payment system and other factors [8]. Lu Wei and Wang Weitong think that economic growth, aging degree and other factors will positively affect per capita public health expenditure through empirical research on provincial panel data from 2002 to 2006 [9]. Through empirical research, He Changjiang finds that there is no inevitable causal relationship between population size, population structure, urbanization and government public health expenditure, and there is a positive correlation between the level of economic development and the expansion of government agencies and personnel and government public health expenditure [10].

There are also many scholars who focus on the study of public health expenditure from the aspects of fiscal system, fiscal expenditure structure and expenditure scale. Among them, Bardhan believes that when there is a clear gap between local and central authorities in terms of personnel quality, technical level and management ability, fiscal decentralization will reduce the efficiency of public goods supply to a certain extent [11]. Fu Yong believes in his research that fiscal decentralization reduces the efficiency of non-economic public goods supply, while the downward transfer payment from the central government promotes the supply of non-economic public goods [12]. Wang Yongjun believes that China's growing regional gap in basic public services has far exceeded the high-profile economic gap and has become a major threat to sustainable economic development and the construction of a harmonious society [13]. Expanding the total amount of transfer payments is far from enough to promote fiscal equalization. More importantly, it is necessary to make fundamental structural reforms to the current transfer payments that focus on control functions and greatly strengthen their redistribution functions. Wang Xiaojie analyzed the scale and structure of public health expenditure in China, and believed that the strength of financial transfer payments and economic strength had a great impact on public health expenditure [14]. Liu Zhenghua analyzed the panel data at the provincial level in China, and the results showed that there was a negative correlation between fiscal decentralization and public health expenditure, while fiscal self-sufficiency and per capita transfer payments had a positive impact on the proportion of public health expenditure [15]. He Changjiang believed that fiscal decentralization has little positive impact on public health expenditure [16]. Zhang Ronglin found that there is a certain correlation between population size, economic development level, urbanization level and public health expenditure, while fiscal decentralization has a small negative impact on public health expenditure [17]. Li Qiyun and Liu Xiaoyong tested the impact of fiscal decentralization and transfer payments on the equalization of public health services in China using provincial panel data from 1997 to 2006 . It was found that the impact of fiscal decentralization and transfer payments on the supply and equalization of public health services depends on which fiscal decentralization indicators and which public health service measurement indicators are used [18].

\subsection{Literature on Fiscal Decentralization and Public Health Expenditure Measurement Indicators}

Fiscal decentralization is a financial system based on government functions or powers, conforms to economic efficiency and fairness, embodies the democratic spirit, adopts a democratic way and has legal protection, all levels of government have relatively independent fiscal revenue and expenditure scope, and handles the relationship between central government and local government and governments. It is also a financial system that the central government gives local governments certain autonomy in debt arrangement, tax administration and budget implementation. At present, the trend of fiscal decentralization is becoming more and more obvious in the world, whether in developed or developing countries. From China's practice, from the tax system reform of " reducing taxes and giving benefits" in the early days of reform and opening up to the fiscal decentralization system established in 1994, from " the central government's decision on improving the socialist market economic system" to " giving local proper tax administration authority under the premise of unifying tax administration" in "the state Council's guidance on pushing forward the reform of the division of financial authority and expenditure responsibility between the central and local governments", China have witnessed all the way from " earnestly implementing the responsibility of local governments to perform financial authority within the scope of central authority, giving full play to the advantages of local governments in strengthening regional affairs management according to local conditions, and mobilizing and protecting the initiative and initiative of local officials in starting businesses."

At present, the academic circles have not reached a unanimous conclusion on the measurement of fiscal decentralization indicators. Among them, Zhang Yan and Gong Liutang, Shen Kun-Rong and Fu Wen Linmainly measure the degree of fiscal revenue decentralization from the relative proportion of provincial fiscal revenue and central fiscal revenue [19, 20]. However, Qiao Baoyun, Fu Yong and Zhang Yan, Wang Wenjian and Qin Chenglin set out from the fiscal expenditure index dimension to construct fiscal decentralization [21-23]. Zhu Hengpeng and Chen Shuo measure fiscal decentralization from the financial autonomy index, that is, the fiscal revenue in the provincial budget is higher than the total fiscal expenditure in the provincial budget [24, 25]. Eble and Yilmaz and He Changjiang added non-tax autonomy to the existing research to measure the degree of fiscal decentralization [26, 27].

From the previous research results, scholars mostly studied public health expenditure from a single factor, and the choice of variables for public health expenditure was mostly based on 
absolute quantities such as total public health expenditure and per capita expenditure, but less on relative quantity indicators such as the proportion of public health expenditure, and lacked systematic, overall and direct empirical analysis among the influencing factors of public health expenditure. However, from the perspective of fiscal decentralization, the results of studying the public health expenditure behavior of local governments in China are very few. With the publication of "Opinions on Deepening the Reform of Medical and Health System" in 2009 and the continuous improvement of China's tax sharing system, public health expenditure and public health development have also changed greatly in recent years. Therefore, it is necessary to empirically study the relationship between fiscal decentralization, transfer payment, economic development, population structure, medical and health institutions, population size, urbanization, education level and local public health expenditure through a multi-factor model.

\section{Measurement Model and Data}

\subsection{Measurement Model}

This study mainly studies the internal mechanism of the impact of fiscal decentralization on public health expenditure of local governments, and analyzes the factors affecting the public health expenditure of local governments in China. When studying the factors affecting public health expenditure, the existing literature generally uses two types of indicators to describe the scale of public health expenditure: one is the absolute indicator, that is, the per capita public health expenditure; the other is the relative indicator, that is, the proportion of public health expenditure. The similarity between these two indicators is that they reflect the scale of local public health expenditure to a certain extent, but the latter only reflects the government's expenditure structure, while the former not only describes the government's expenditure structure, but also reflects factors such as population and economy related to public expenditure. Based on this, this study uses per capita index and proportion index to respectively establish measurement model and empirically analyze the impact of fiscal decentralization on local public health expenditure.

(1) per capita health expenditure model:

$$
\begin{gathered}
\mathrm{E}_{\mathrm{it}}=\mathrm{a}_{0}+\mathrm{a}_{1} \text { FD }_{\mathrm{it}}+\mathrm{a}_{2} \text { LNTRANSFER }_{\mathrm{it}}+\mathrm{a}_{3} \text { LNLNPGDP }_{\mathrm{it}}+\mathrm{a}_{4} \text { LNHN } \\
\text { UM }_{\mathrm{it}}+\mathrm{a}_{5} \text { POPS }_{\mathrm{it}}+\mathrm{a}_{6} \text { URBAN }_{\mathrm{it}}+\mathrm{a}_{7} \text { ILR }_{\mathrm{it}}+\eta_{\mathrm{i}}+\theta_{\mathrm{t}}+\varepsilon_{\mathrm{it}}
\end{gathered}
$$

(2) public health expenditure proportion model:

$$
\begin{gathered}
\mathrm{Y}_{\mathrm{it}}=\mathrm{a}_{0}+\mathrm{a}_{1} \text { FD }_{\mathrm{it}}+\mathrm{a}_{2} \text { LNTRANSFER }_{\mathrm{it}}+\mathrm{a}_{3} \text { LNPGDP }_{\mathrm{it}}+\mathrm{a}_{4} \text { LNHNU } \\
\text { M }_{\mathrm{it}}+\mathrm{a}_{5} \text { POPS }_{\mathrm{it}}+\mathrm{a}_{6} \text { URBAN }_{\mathrm{it}}+\mathrm{a}_{7} \mathrm{ILR}_{\mathrm{it}}+\eta_{\mathrm{i}}+\theta_{\mathrm{t}}+\varepsilon_{\mathrm{it}}
\end{gathered}
$$

Where, subscripts i represents provinces, municipalities and autonomous regions, and $t$ represents years.

In model (1), the explained variable $E_{i t}$ represents the per capita public health expenditure of province i (municipality directly under the central government and autonomous region) in year $\mathrm{t}$.

In model (2), the explained variable $Y_{\text {it }}$ represents the proportion of public health expenditure in the fiscal expenditure of province $\mathrm{i}$ (municipality directly under the central government and autonomous region) in year t. The explanatory variable $\mathrm{FD}_{\mathrm{it}}$ represents the fiscal decentralization of local governments and reflects the degree of autonomy of

\begin{tabular}{|c|c|c|}
\hline Type & Variable name and symbol & Measurement index \\
\hline \multirow{2}{*}{$\begin{array}{l}\text { The dependent } \\
\text { variable }\end{array}$} & \multirow{2}{*}{$\begin{array}{l}\text { Per capita expenditure on public health } \mathrm{E}_{\mathrm{it}} \\
\text { Public health expenditure as a share of fiscal } \\
\text { expenditure } Y_{\mathrm{it}}\end{array}$} & Per capita public health expenditure level within the budget \\
\hline & & The proportion of public health expenditure in the budget to total fiscal expenditure \\
\hline \multirow{6}{*}{$\begin{array}{l}\text { Explanatory } \\
\text { variables }\end{array}$} & \multirow{3}{*}{$\begin{array}{l}\text { Fiscal decentralization } \mathrm{FD}_{\mathrm{it}} \\
\text { per capita Transfer payment } \\
\text { TRANSFER }_{\text {it }} \\
\text { per capita GDP } \\
\text { Total number of grassroots health institutions and } \\
\text { professional public health institutions LNHNUM } \\
\text { it }\end{array}$} & Reflect the fiscal decentralization of local governments \\
\hline & & Reflect the central government's per capita transfer payments to the region \\
\hline & & Reflect the level of local economic development \\
\hline & Population dependency ratio POPS $_{\text {it }}$ & $\begin{array}{l}\text { The population structure is reflected by the ratio of the population of } 0-14 \text { years old } \\
\text { and above and the total population between the ages of } 15 \text { and } 64 \text { in each region }\end{array}$ \\
\hline & Degree of urbanization $\mathrm{URBAN}_{\mathrm{it}}$ & $\begin{array}{l}\text { The degree of urbanization is reflected by the ratio of the urban population to the } \\
\text { total population in each region. }\end{array}$ \\
\hline & Illiteracy rate $\mathrm{ILR}_{\text {it }}$ & $\begin{array}{l}\text { Reflect the educational level by the ratio of the number of illiterate people over the } \\
\text { age of } 15 \text { to the total population over the age of } 15\end{array}$ \\
\hline
\end{tabular}
local fiscal expenditure. The other variables are defined in table 1 below.

Table 1. Definition of variables.

These explanatory variables are divided into two parts. The first part, with $\mathrm{FD}_{\mathrm{it}}$ and LNTRANSFER $\mathrm{it}_{\mathrm{it}}$ as the core variables, respectively reflects the fiscal freedom of local governments and the impact of government incentives on local public health expenditure to a certain extent, which is also the focus of this study. The second part contains LNLNPGDP $_{i t}$, LNHNUM $_{\text {it }}$, POPS $_{\text {it }}, \mathrm{URBAN}_{\mathrm{it}}, \mathrm{ILR}_{\mathrm{it}}$ and other control variables, reflecting other major factors affecting local public health expenditure.

Fiscal decentralization reflects the size of the government's fiscal autonomy. The greater the decentralization, the greater the fiscal freedom of local governments, and local governments are likely to change their behavior or expenditure direction according to the direction of incentives. As mentioned above, as for the measurement of fiscal decentralization, different researchers have given different 
methods [28]. Currently, there are mainly four indicators that are frequently used: revenue index, expenditure index, fiscal autonomy index, non-tax autonomy degree [29]. The revenue index and expenditure index mainly refer to the proportion of local fiscal revenue (expenditure) in the national fiscal fevenue (expenditure). The degree of fiscal autonomy also refers to the rate of fiscal autonomy, which mainly measures the ability of local governments to finance their expenditures by relying on their own revenue. The degree of non-tax autonomy measures the ability of local governments to collect special income, administrative fee income, fines and confiscation income, state-owned capital operating income, state-owned resources (assets) paid use income, and other non-tax revenues [30]. As different indicators may produce different analysis results, in order to improve the robustness of the model, this study uses three fiscal decentralization measures of fiscal revenue decentralization degree, fiscal autonomy degree and non-tax autonomy degree as key variables to study the impact of different fiscal decentralization indexes on public health expenditure of local governments.

(1) Fiscal decentralization of income indicator $\mathrm{FRI}_{\mathrm{it}}=$
Provincial budgetary revenue $_{i t} /$ Central budgetary revenue within the budget $_{\text {it }}$

(2) Financial autonomy $\mathrm{FAI}_{\mathrm{it}}=$ Provincial budgetary revenue $_{\text {it }} /$ Provincial total budgetary expenditure $_{i t}$

(3) Non-tax autonomy degree FISD $_{\text {it }}=$ Non-tax revenues of provinces, municipalities and autonomous regions $\mathrm{s}_{\mathrm{it}} /$ Actual fiscal revenue of provinces, municipalities and autonomous regions $_{\text {it }}$

\subsection{Data Sources and Descriptive Statistics}

Since the "Opinions on Deepening the Reform of the Medical and Health System" was introduced in 2009, this study selects the data for the period from 2010 to 2015 . The data mainly comes from the China Statistical Yearbook, the China Health Statistics Yearbook, the China Financial Statistics Yearbook and reports on the annual budget implementation of 31 provinces, municipalities and autonomous regions and the draft budget for the coming year. In order to eliminate the possible effects of heteroscedasticity, this study takes a logarithmic form of some data. Descriptive statistics of each variable are shown in Table 2.

Table 2. Descriptive statistics of each variable.

\begin{tabular}{|c|c|c|c|c|c|}
\hline Variables & value & Mean & Std & Min & Max \\
\hline $\mathrm{Y}_{\mathrm{it}}$ & 186 & 6.963226 & 1.385586 & 3.97 & 10.56 \\
\hline $\mathrm{E}_{\mathrm{it}}$ & 186 & 687.1925 & 292.592 & 261.55 & 1938.45 \\
\hline $\mathrm{FRI}_{\mathrm{it}}$ & 186 & 0.783482 & 1.003308 & 0.066606 & 7.968419 \\
\hline FAI $_{\text {it }}$ & 186 & 0.524793 & 0.338213 & 0.066546 & 2.365331 \\
\hline FISD $_{\text {it }}$ & 186 & 0.246774 & 0.084126 & 0.04 & 0.43 \\
\hline Per capita TRANSFER $_{\text {it }}$ & 186 & 2910.63 & 4180.575 & 323.35 & 39657.38 \\
\hline Per capita GDP ${ }_{i t}$ & 186 & 44568.44 & 21265.42 & 13119 & 107960.1 \\
\hline POPS $_{\text {it }}$ & 186 & 34.87376 & 6.547168 & 19.27 & 51.04 \\
\hline URBAN $_{\text {it }}$ & 186 & 53.86527 & 13.91019 & 22.67 & 89.6 \\
\hline ILR $_{\text {it }}$ & 186 & 6.087796 & 5.975479 & 1.46 & 41.52 \\
\hline
\end{tabular}

\section{Empirical Results Analysis}

\subsection{Regression Results}

In this study, since the differences between provinces are unobservable, mixed regression models cannot be used. Instead, fixed effects or random effects models should be used for estimation, and Hauseman test should be used to examine whether fixed effect models or random effects models should be selected. The results show that the results of the Hauseman test support the fixed effect model, and the static estimation results are omitted due to layout restrictions.

In order to test the robustness of the results, this study uses the test methods (Cochrane-Orcutt) and xttest 3 commands to test the autocorrelation and heteroscedasticity of the model. The results show that the model has autocorrelation and heteroscedasticity. To reduce the influence of autocorrelation and heteroscedasticity on the robustness of measurement results, the feasible generalized least square method (FGLS) is adopted, and the results are shown in table 3.

Table 3. Generalized least squares (FGLS) estimation results.

\begin{tabular}{|c|c|c|c|c|c|c|c|}
\hline \multirow{2}{*}{ Variables } & \multirow{2}{*}{ Parameter } & \multicolumn{3}{|l|}{$\mathbf{E}_{\mathrm{it}}$} & \multicolumn{3}{|l|}{$\mathbf{Y}_{\mathrm{it}}$} \\
\hline & & M1 & M2 & M3 & M1 & M2 & M3 \\
\hline $\mathrm{FRI}_{\text {it }}$ & $\mathrm{a}_{1}$ & $0.1231^{* * *}(0.0194)$ & - & - & $-0.0163(0.0998)$ & - & - \\
\hline FAI $_{\text {it }}$ & $a_{1}$ & - & $\begin{array}{l}0.2515^{* * *} \\
(0.0557)\end{array}$ & - & - & $0.4638^{*}(0.2718)$ & - \\
\hline FISD $_{\text {it }}$ & $a_{1}$ & - & - & $-0.3086(0.2114)$ & - & - & $\begin{array}{c}-2.9094^{* * *} \\
(0.9684)\end{array}$ \\
\hline $\begin{array}{l}\text { Per capita } \\
\text { TRANSFER }_{\text {it }}\end{array}$ & $\mathrm{a}_{2}$ & $0.2282^{* * *}(0.0202)$ & $\begin{array}{l}0.2293^{* * *} \\
(0.0213)\end{array}$ & $0.2223^{* * *}(0.0227)$ & $\begin{array}{l}0.2189^{* *} \\
(0.1041)\end{array}$ & $0.2485^{* *}(0.1040)$ & $\begin{array}{l}0.2965^{* * *} \\
(0.1042)\end{array}$ \\
\hline Per capita GDP it $_{\text {it }}$ & $\mathrm{a}_{3}$ & $0.6313^{* * *}(0.0826)$ & $\begin{array}{c}0.5789^{* * *} \\
(0.0855)\end{array}$ & $0.5348^{* * *}(0.0890)$ & $\begin{array}{c}-0.7895^{* *} \\
(0.4246)\end{array}$ & $-0.6987^{*}(0.4169)$ & $\begin{array}{c}-0.7927^{* *} \\
(0.4079)\end{array}$ \\
\hline LNHNUM $_{\text {it }}$ & $\mathrm{a}_{4}$ & $-0.1621^{* * *}(0.02059)$ & $-0.1595^{* * *}$ & $-0.1394^{* * *}$ & $0.8593^{* * *}$ & $0.8306^{* * *}(0.1053)$ & $0.9106^{* * *}$ \\
\hline
\end{tabular}




\begin{tabular}{|c|c|c|c|c|c|c|c|}
\hline \multirow{2}{*}{ Variables } & \multirow{2}{*}{ Parameter } & \multicolumn{3}{|l|}{$\overline{E_{i t}}$} & \multicolumn{3}{|l|}{$\overline{Y_{\text {it }}}$} \\
\hline & & M1 & M2 & M3 & M1 & M2 & M3 \\
\hline & & & $(0.0216)$ & $(0.0227)$ & $(0.1059)$ & & $(0.1041)$ \\
\hline POPS $_{\text {it }}$ & $a_{5}$ & $0.0138^{* * *}(0.0031)$ & $\begin{array}{l}0.0148^{* * *} \\
(0.0032)\end{array}$ & $0.0178^{* * *}(0.0034)$ & $\begin{array}{l}0.1201^{* * *} \\
(0.0161)\end{array}$ & $0.1158^{* * *}(0.0159)$ & $\begin{array}{l}0.1281^{* * *} \\
(0.0158)\end{array}$ \\
\hline $\mathrm{URBAN}_{\mathrm{it}}$ & $\mathrm{a}_{6}$ & $-0.0089^{* *}(0.0038)$ & $\begin{array}{l}-0.0040 \\
(0.0037)\end{array}$ & $0.0017(0.0036)$ & $\begin{array}{l}0.0544^{* * *} \\
(0.0194)\end{array}$ & $0.0418^{* *}(0.0183)$ & $\begin{array}{l}0.0502^{* * *} \\
(0.0169)\end{array}$ \\
\hline $\mathrm{ILR}_{\mathrm{it}}$ & $a_{7}$ & $0.0049(0.0033)$ & $\begin{array}{l}0.0082^{* *} \\
(0.0033)\end{array}$ & $0.0102^{* * *}(0.0035)$ & $-0.0241(0.0168)$ & $-0.0299(0.0162)$ & $\begin{array}{l}-0.0325^{* *} \\
(0.0159)\end{array}$ \\
\hline
\end{tabular}

Notes: Standard deviation (SE) is in parentheses, * indicates a significant test at the $10 \%$ level; ** indicates a significant test at the $5 \%$ level; *** indicates a significant level at the $1 \%$ level Sex test.

However, none of the above models have considered endogenous problems, which may lead to biased and inconsistent results. In this study, endogeneity problems mainly come from two aspects: on one hand, there may be biases caused by missing variables. Public health expenditures are affected by a variety of observable and unobservable factors, which may not be considered in the model, but are classified as errors. If a missing variable is related to other explanatory variables, it may lead to endogeneity problem. On the other hand, there may be a two-way interaction between public health expenditures and explanatory variables. For example, there may be a causal relationship between the economic development level of a region and public health expenditure, between dependency ratio and public health expenditure, between the total number of health institutions and public health expenditure. This study solves these endogenous problems by adopting the lag period instrumental variable strategy. The lag phase of the variables such as the per capita GDP, the dependency ratio, the primary health institutions and the total number of professional public health institutions is used as the instrumental variable. The regression was conducted based on the generalized method of moment estimation (GMM) with fixed effects. The results are shown in table 4.

Table 4. Dynamic panel estimation results.

\begin{tabular}{|c|c|c|c|c|c|c|c|}
\hline \multirow{2}{*}{ Variables } & \multirow{2}{*}{ Parameter } & \multicolumn{3}{|l|}{$\mathbf{E}_{\text {it }}$} & \multicolumn{3}{|l|}{$Y_{\text {it }}$} \\
\hline & & M1 & M2 & M3 & M1 & M2 & M3 \\
\hline$\overline{\text { FRI }_{\text {it }}}$ & $\mathrm{a}_{1}$ & $0.1120^{* * *}(0.0334)$ & - & - & $-0.0388(0.1011)$ & - & - \\
\hline $\mathrm{FAI}_{\mathrm{it}}$ & $a_{1}$ & - & $\begin{array}{l}0.2381^{* * *} \\
(0.0478)\end{array}$ & - & - & $0.3360(0.3399)$ & - \\
\hline FISD $_{\text {it }}$ & $\mathrm{a}_{1}$ & - & - & $-0.4582^{* *}(0.2191)$ & - & - & $\begin{array}{l}-3.3879^{* * *} \\
(1.0420)\end{array}$ \\
\hline $\begin{array}{l}\text { Per capita } \\
\text { TRANSFER }_{\text {it }}\end{array}$ & $\mathrm{a}_{2}$ & $0.2026^{* * *}(0.0180)$ & $\begin{array}{l}0.2053^{* * *} \\
(0.0192)\end{array}$ & $0.1976^{* * *}(0.0206)$ & $0.1722^{*}(0.1017)$ & $0.2035^{* *}(0.0971)$ & $\begin{array}{l}0.2565^{* *} \\
(0.1013)\end{array}$ \\
\hline $\begin{array}{l}\text { Per capita } \\
\text { GDP }_{\text {it }}\end{array}$ & $\mathrm{a}_{3}$ & $0.5298^{* * *}(0.0881)$ & $\begin{array}{l}0.4855^{* * *} \\
(0.0817)\end{array}$ & $0.4397^{* * *}(0.0852)$ & $-1.0279^{*}(0.5534)$ & $-0.9523^{*}(0.5447)$ & $\begin{array}{l}-1.0859^{* *} \\
(0.5237)\end{array}$ \\
\hline LNHNUM $_{\mathrm{it}}$ & $\mathrm{a}_{4}$ & $-0.1637^{* * *}(0.0179)$ & $\begin{array}{l}-0.1624^{* *} \\
{ }^{*}(0.0190)\end{array}$ & $-0.1443^{* * *}(0.0219)$ & $0.9015^{* * *}(0.1222)$ & $0.8832^{* * *}(0.1241)$ & $\begin{array}{l}0.9568^{* * *} \\
(0.1197)\end{array}$ \\
\hline POPS $_{\text {it }}$ & $a_{5}$ & $0.0126^{* * *}(0.0024)$ & $\begin{array}{l}0.0131^{* * *} \\
(0.0025)\end{array}$ & $0.0168^{* * *}(0.0026)$ & $0.1238^{* * *}(0.0175)$ & $0.1197^{* * *}(0.0171)$ & $\begin{array}{l}0.1341^{* * *} \\
(0.0170)\end{array}$ \\
\hline URBAN $_{i t}$ & $\mathrm{a}_{6}$ & $-0.0076^{*}(0.0041)$ & $\begin{array}{l}-0.0036 \\
(0.0036)\end{array}$ & $0.0018(0.0036)$ & $0.0610^{* *}(0.0259)$ & $0.0498^{* *}(0.0248)$ & $\begin{array}{l}0.0566^{* *} \\
(0.0223)\end{array}$ \\
\hline $\mathrm{ILR}_{\mathrm{it}}$ & $\mathrm{a}_{7}$ & $0.0035^{*}(0.0021)$ & $\begin{array}{l}0.0062^{* *} \\
(0.0026)\end{array}$ & $0.0075^{* * *}(0.0027)$ & $-0.0257(0.0179)$ & $-0.0311(0.0183)$ & $\begin{array}{l}-0.0363^{*} \\
(0.0199)\end{array}$ \\
\hline
\end{tabular}

Notes: Standard deviation (SE) is in parentheses, * indicates a significant test at the $10 \%$ level; $* *$ indicates a significant test at the $5 \%$ level; $* * *$ indicates a significant level at the $1 \%$ level Sex test, the model passed the weak tool variable test. Comparing Table 3, it can be seen that the sign of the key variable coefficient has not changed, but it is more significant, and the empirical research results have good robustness.

\subsection{Empirical Analysis}

From the sample analysis, for different fiscal decentralization indicators, the impact on public health expenditure is also different. Among them. The coefficients of fiscal decentralization of income indicator $\mathrm{FRI}_{\mathrm{it}}$ and financial autonomy $\mathrm{FAI}_{\mathrm{it}}$ are significantly positive, indicating that local governments who have relatively large fiscal autonomous income rights can effectively increase public health expenditure. The non-tax autonomy degree FISD $_{\text {it }}$ has a significant negative effect, indicating that the higher the proportion of non-tax revenue in a region, the lower the public health expenditure will be reduced to some extent, which further confirms that higher local tax revenue capacity has a positive effect on public health expenditure. And it also confirms the research conclusions of Anyuan and Wang Wei [31] that fiscal decentralization has promoted the local government's emphasis on economic construction expenditure and ignorance of the expenditure of science, education, culture and health.

From the perspective of control variables, the per capita transfer payment index TRANSFER it $_{\text {coefficient is }}$ significantly positive, indicating that the central transfer payment for local has a significant positive effect on local government public health expenditure. The coefficient of per capita $\mathrm{GDP}_{\mathrm{it}}$ is significantly positive, and the government's 
public health expenditure increases by about 0.5 units with one unit of economic growth. To a certain extent, this proves the rationality of Wagner's Law, the imbalance of economic development which leads to the imbalance of public health investment in various regions has aggravated the gap in the supply of basic medical and health services between regions. Other control variables also have a significant impact on local public health spending.

From the overall regression results, besides the non-tax autonomous degree FISD $_{\text {it }}$ decentralization index, other decentralization indicators are generally not significant. Among them, the income index fiscal decentralization $\mathrm{FRI}_{\mathrm{it}}$ and non-tax autonomy degree FISD $_{\text {it }}$ coefficient is negative, indicating that the greater the financial autonomy, the higher the fiscal capacity, the lower the proportion of public health expenditure, the government's enthusiasm for public health expenditure will be reduced. In terms of relative volume, local governments are still less motivated to provide non-productive public goods.

\section{Conclusions and Policy Recommendations}

This study makes an empirical analysis of the influencing mechanism of local public health expenditure from the perspective of fiscal decentralization by building a model of influencing local public health expenditure. The research results show that:

(1) Different fiscal decentralization indicators and public health expenditure indicators will get inconsistent conclusions, indicating that the supply mechanism of public health expenditure should be analyzed from multiple perspectives. The impact of fiscal decentralization on public health expenditure needs to be further comprehensively studied, instead of being limited to a single measurement indicator. However, from the overall point of view, the increase of local financial autonomy has a certain role in promoting the absolute amount of public health expenditure, but it has little effect or even has a negative effect on the proportion of public health expenditure. From both national and local perspectives, there is a serious shortage of public health expenditure in China. On the surface, the total amount of public health expenditure is constantly increasing, but the proportion of public health expenditure to fiscal expenditure does not increase with economic development. The current fiscal decentralization system plays a role in promoting this phenomenon to some extent, which makes local governments often neglect the supply of public health products for economic growth. And there is a long way to go to equalize public health services in China.

(2) If China's fiscal decentralization system aggravates the imbalance of public health expenditure in various regions, then central transfer payment increases the balance to some extent and significantly promotes the effective supply of public health products. However, the effect of central transfer payment on stimulating local governments to increase public health spending is obviously less significant than the effect of local governments' own financial increase. It can be seen that to promote the equalization of public health services in China, the central government should continue to increase transfer payments, standardize the supporting policies of special transfer payments, and continue to promote the equalization of basic public services. On the other hand, it is more important to further reasonably divide the fiscal authorities of the central and local governments, clarify the spending responsibility boundary between the central and local governments, and at the same time establish a hard constraint mechanism of the central and local public health expenditure to enhance its accountability, and improve the enthusiasm of local governments to provide non-productive public goods.

(3) The government should implement measures combining central supervision and control with local financial autonomy to ensure the effective supply of local public health products. On one hand, on the basis of establishing a fiscal system with matching financial and authority rights and a standardized fiscal transfer payment system, the government should further improve the assessment mechanism of local officials, reform the assessment of the performance of GDP only, and incorporate public health, education development and other public goods that are related to the vital interests of the people into the official performance assessment system, so that local governments pay more attention to people's livelihood construction while developing regional economy. At the same time, it is necessary to improve the budget management system, and focus on the review of the general public budget from the balance state, the deficit scale to the expenditure budget and policies, and implement the review of key expenditure items, which objectively plays a role in "protecting and escorting" public health expenditure projects. This is also reflected in the Third Plenary Session of the 18th Central Committee of the Communist Party of China, "The Decision of the Central Committee of the Communist Party of China on Comprehensively Deepening the Reform of Some Major Issues."On the other hand, the central government should give full play to local financial autonomy. How come the local income? How to spend? All of these must be listened to by the local people. The central government must give full play to the supervision and restraint of local democracy on local government behavior, so that local finance can solve the problems and difficulties that local people concerned.

(4) Through this study, besides fiscal decentralization and central transfer payment, the economic development level, urbanization rate, population number, population structure and education level of a region also affect local 
fiscal health expenditure. Therefore, in the case of large differences in economic development level, population size, urbanization level, aging degree and population structure of different regions, governments at all levels should take the actual situation of the region into full consideration when making public health expenditure arrangements. In the same way, the central government should reasonably define the intensity of public health transfer payments to each region in accordance with local financial resources, economic development, population size and population structure, rather than "one size fits all".

\section{References}

[1] Chen Gong, Wang Jun, "Finance and public health", Beijing: Renmin University of China Press, 2007.

[2] Ulf-G. Gerdtham and Magnus Johannesson, “Absolute Income, Relative Income, Income Inequality, and Mortality", The Journal of Human Resources, Vol. 39, No. 1 (Winter, 2004), pp. 228-247.

[3] Newhouse, Joseph, P.\& Friedlander, Lindy, "The Relationship between Medical Resources and Measures of Health: Some Additional Evidence", The Journal of Human Resource, Vol. 15, No. 2 (Spring, 1980), pp. 200-218.

[4] Fatás, Antonio, and A. K. Rose. "Do Monetary Handcuffs Restrain Leviathan? Fiscal Policy in Extreme Exchange Rate Regimes." Cepr Discussion Papers 47.2692(2001): 2692.

[5] Tanzi V, Schuknecht L, "Public Spending in the 20th Century", Cambridge, Cambridge University Press, 2000.

[6] Sanjay Pradhan, "Basic method of public expenditure analysis", Beijing, China financial and economic press, 2000.

[7] Michael Grossman, "On the Concept of Health Capital and the Demand for Health", Journal of Political Economy, Vol. 80, No. 2 (Mar. - Apr., 1972), pp. 223-255.

[8] Chen Gong, Wang Jun, "Finance and public health", Beijing, Renmin University of China Press, 2007.

[9] Lu Wei, Wang Weitong, "Study on the equalization of basic public services in China - an analysis based on the perspective of public demand and government capacity", Financial research, 2008 (5), PP.10-18.

[10] He Changjiang, "Empirical analysis of factors influencing government public health expenditure behavior", Financial Science, 2011(4), PP.94-100.

[11] Bardhan, Pranab, "Decentralization of Governance and Development", Journal ofEconomic Perspectives, Vol.16, No.4(2002). Autumn, pp.185-205.

[12] Fu Yong, "Fiscal decentralization, government governance and non-economic public goods supply", Economic Research, 2010(8), PP.4-16.

[13] Wang Yongjun, " Fiscal equalization and reform of transfer payment system in China", Journal of Central University of Finance and Economics, 2006(9), PP.1-5.

[14] Wang Xiaojie, "Theory and empirical analysis of China's public health expenditure", Beijing, Renmin University of China.

[15] Liu Zhenghua, Lu zongyao, "Fiscal decentralization and public health expenditure: empirical evidence from China's provincial level", China Health Economy, 2014(10), PP.58-60.

[16] He Changjiang, "Empirical analysis of factors influencing government public health expenditure behavior", Financial Science, 2011(4), PP.94-100.

[17] Zhang Ronglin, Qian yu, Liu songsong, "Empirical analysis of public health expenditure behavior of local governments in China”, East China Economic Management, 2012(4), PP.131-135.

[18] Li Qiyun, Liu xiaoyong, "Empirical study on fiscal decentralization, transfer payment and equalization of regional public health services", Journal of Shandong University, Philosophical and Social Science Edition, 2010(5), PP.34-46.

[19] Zhang Yan, Gong Liutang, "Tax reform, Fiscal Decentralization and China's Economic Growth”, Economics (quarterly). 2005(4), PP.75-108.

[20] Shen Kunrong, Fu Wenlin, "China's fiscal decentralization system and regional economic growth", Management World.2005(1), PP.31-39.

[21] Qiao Baoyun, "The trade-off between growth and equality - China's fiscal decentralization policy research", Beijing, People's Publishing House, 2002.

[22] Fu Yong and Zhang Yan, "Chinese decentralization and fiscal expenditure structure bias: the cost of competition for growth", Management World, 2007(3), PP.4-12.

[23] Wang Wenjian, Tan Chenglin, "Regional differences in the growth effects of local government behavior and fiscal decentralization”, Management World, 2008(1), PP.9-21.

[24] Zhu Hengpeng, "Decentralization reform, fiscal incentives and restructuring of public enterprises", World Economy, 2004(12), PP.14-24.

[25] Chen Shuo, "Tax reform, local fiscal autonomy and public goods supply”, Economics (quarterly), 2010(4), PP.1427-1446.

[26] Ebel, r.d., Yilmaz, S., "On the Measurement and Impact of Fiscal Decentralization", World Bank Policy ResearchWorking Paper, 2002, No. 2809.

[27] He Changjiang, "Empirical analysis of factors influencing government public health expenditure behavior", Financial Science, 2011 (4), PP. 94-100.

[28] Chen Shuo, Gao Lin, "Central-local Relationship: Fiscal Decentralization Measurement and Reassessment of the Mechanism of Action". Management World, 2012 (6), PP.43-59.

[29] Ebel, r.d., Yilmaz, S., "On the Measurement and Impact of Fiscal Decentralization", World Bank Policy ResearchWorking Paper, 2002, No. 2809.

[30] Zhang Yan, Gong Liutang, "Tax reform, Fiscal Decentralization and China's Economic Growth", Economics (quarterly). 2005(4), PP.75-108.

[31] An Yuan and Wang Jun, "Dynamic Evolution of Fiscal Decentralization and Expenditure Bias -- Analysis Based on Non-parametric Point-by-Point Estimation", Economist, 2010(7), PP.42-50. 